Journal of Advanced Research in Business

and Management Studies

\title{
Enterprise Risk Management (ERM) Behaviour Matrix: Mapping ERM Implementations of Non-Financial Public Listed Companies in Malaysia
}

\author{
Zakiah Abdul Khalik ${ }^{1}$, Rabihah Md. Sum ${ }^{1, *}$ \\ 1 Faculty of Science and Technology, Universiti Sains Islam Malaysia (USIM), Bandar Baru Nilai, 71800 Nilai, Negeri Sembilan, Malaysia
}

\section{ARTICLE INFO}

\section{Article history:}

Received 7 May 2020

Received in revised form 6 June 2020

Accepted 7 June 2017

Available online 14 June 2020

\section{Keywords:}

Enterprise risk management, ERM, ERM

implementation, ERM score, ERM

behavior

\section{ABSTRACT}

This study investigates ERM implementation of non-financial public listed companies (PLCS) in Malaysia against company size and leverage. The ERM implementation is proxy by ERM Score. The ERM Score is based on COSO ERM Framework. Company size and leverage is proxy by total revenues and liabilities/equities. The objective is to observe changes in ERM implementation in response to changes in company size and leverage. This study develops a 3 by 3 matrix named ERM Behaviour Matrix to understand the changes. The behaviour matrix captures changes in ERM implementation by mapping the ERM Score against company size and leverage. The ERM implementation behaviour is defined as changes in ERM implementation driven by two stimuli, company size, and leverage. Data are collected from annual reports 2016-2017. The study samples are 44 non-financial PLCs of high-risk sectors (energy, utilities, and telecommunications and media). The matrix shows positive ERM behaviours for company size. ERM scores increases as firm size increases, and decreases as firm size decreases. The matrix shows mixed ERM behaviours for leverage. A number of companies' shows status-quo behaviour i.e. as leverage increases, ERM Score remain constant. In contrast, several companies' shows negative behaviour, i.e. as leverage increases, ERM Score decreases. The matrix is an alternative approach to understand ERM implementation. It is a simple and easy to use behaviour tool mapping ERM implementation against firm size and firm advantage. It can be use in practice to monitor ERM implementation by companies. Results of this study contribute to enhance understanding on ERM implementation by public limited companies (PLCS) in Malaysia.

\footnotetext{
* Corresponding author.

E-mail address: rabihah@usim.edu.my
}

https://doi.org/10.37934/arbms.19.1.4259 


\section{Introduction}

The objective of implementing ERM is to provide a reasonable assurance that companies can achieved their business objective and enhances value [35]. Companies cannot eliminate risks. Therefore, they implement ERM as a strategic planning tool to identify, manage, and respond to risks effectively [14, 6]. ERM helps management to understand their key business risks [33] while establishing strong risk management culture across the company [21].

ERM is new concept in majority countries of Asia [30]. In Malaysia, even though ERM practices are increasing, not all companies adopted ERM [45]. The development and application of ERM is rather limited in practices [34]. According to [46], despite more attention given to ERM in past years, ERM is still not widely practiced in Malaysia. ERM implementation is still at a low level particularly among PLCs [34]. The study examines ERM practices by PLCs listed on Bursa Malaysia's main market. The results, ERM practices are at infancy level, and only $30 \%$ of the sample companies implemented ERM programs [34].

This current study was motivated by the previous studies $[30,34,46]$. This study argues that ERM is relatively a new concept in Malaysia and limited in practices. Studies investigating ERM implementation in various industries in Malaysia are also limited. Against this backdrop, this study investigates the behavior of enterprise risk management (ERM) implementations by Malaysian nonfinancial public listed companies (PLCs) in response to two stimuli, company size, and leverage. The objective is to understand how do companies' ERM implementation changes company size and leverage changes. The study focuses on two variables, company size and leverage. Company size and leverage are two common factors use as independent variables in studies investigating ERM implementations. Majority of the studies either use linear or logistic regression to determine the influence of company size and leverage on ERM implementations. This study, on the other hand, develops ERM Behaviour Matrix. The ERM Behaviour Matrix develops in this study presented an alternative approach to understand ERM implementation against company size and leverage. Results of this study contribute to enhance knowledge on ERM implementation by PLCs in Malaysia. It contributes to the existing body of knowledge on ERM implementation by companies in Malaysia. The matrix is a simple and easy to use behaviour tool, mapping ERM implementation against firm size and leverage. It can be use in practice by regulators, policy makers and authorities to monitor companies' ERM implementation.

\section{ERM Implementation Measurement}

\subsection{ERM Proxy or Keyword Search.}

ERM proxy search uses ERM related keywords as a proxy of ERM implementation [6, 11, 23, 26, $36,44]$. Examples are Chief Risk Officer, risk management committee, board risk management committee, and audit committee. The keyword search methodology is a common method to determine ERM implementation in companies. However, the limitation of keywords search is it cannot measure levels of ERM implementation. Regardless, studies still use the keyword search methodology to detect ERM implementation [16, 32]. Ten out of twenty-five studies use keywords as proxy for ERM implementation [24].

\subsection{ERM Rating from Standard \& Poor's.}

ERM implementation can be detected based on the ERM rating of Standard and Poor's (S\&P) [27, $31,37]$. S\&P ERM Rating is an assessment tool to measure level of ERM implementation. Initially, S\&P 
develops ERM Quality Scale [39], for assessing level of ERM implementation for insurance companies. Later, S\&P expands and integrates the scale with ERM characteristics for banking and non-financial companies. Originally, the S\&P ERM Quality Scale consists of four categories: weak, adequate, strong, and excellent. In 2009, S\&P revises the scale into five categories: weak, adequate, adequate with risk controls, strong and very strong [40]. A weak or adequate level indicates a traditional risk management implementation, instead of ERM. Strong and excellent levels indicate an ERM implementation [31].

\subsection{ERM Index.}

ERM index is a measurement tool to determine level of ERM implementation. $[9,10,38]$ used COSO ERM Framework as the basis for their ERM index development. The COSO ERM effectiveness index by [38] is developed by assessing a company's capability to meet its objectives for strategy, operations, reporting, and compliance. [9] developed a questionnaire consists of 70 items based on COSO ERM Framework's eight components. The components are internal environment, objective setting, event identification, risk assessment, risk response, control activities, information and communication, and monitoring. The questionnaire items are being assessed as absence (scored as zero " 0 ") or as presence (scored as one "1"). Later, [10] developed a similar list of 108 questions and scoring. [20] used an ERM survey by Tilinghast Towers Perrin as a basis for developing an ERM index. The index evaluates ERM implementation for the insurance industry. The index evaluates economic capital model and metric of market value based risk, CRO or significant risk management entity, the board, the CFO, the CEO or a committee having responsibility for risk management reports, risk management being used to influence executive compensation and the risks being revealed in the company's decision making.

\section{ERM Implementation Factors}

\subsection{Company Size.}

ERM implementation levels among companies varies [5,6]. [7] argued that ERM implementation depends on the industry size. Generally, bigger company size with complex risks requires ERM implementation. Bigger companies are likely to adopt and implement ERM due to their relatively high complex business [23]. The companies face various risks and their company size enables them to absorb the administrative and operational costs of ERM implementation. Bigger companies are inclined to allocate more resources to implement ERM. [5, 18, 48]. [11] also agreed that ERM implementation is influenced by company size. In other words, company sizes have positive relationship with ERM implementation [7]. According to [12], as companies' size increases, the companies' exposure to risks also increases. The larger the risk exposures, increases the possibility to implementing ERM. In addition, as companies increase the scope of their business, their risk exposures become more complex. Hence, these large companies need ERM to manage their risks [17], and being large companies, they have the resources to invest in ERM [25]. In addition, previous studies commonly use company size as a control variable in the studies of ERM and firm value. For example, [38] used company size as a control variable, and finds company size had a positive influence on firm performance. Several studies have also use company size as a control variable in their investigation on the relationship between ERM implementation and firm value $[13,20,25,27$, 47]. Their results agree with [38], company size has positive influence on ERM implementation and firm value. 


\subsection{Financial Leverage.}

Companies use both debt and equity to finance their business operations. Leverage or financial leverage is the ratio between total debt and total equity. Leverage measure how much a company's capital is from debt (debtholders) in comparison to from equities (shareholders). Companies with larger amount of debt compared to equity have higher chances of not being able to pay off the debt's interest or principal. Generally, companies with higher leverage have to manage the risk of bankruptcy or financial difficulty. Hence, highly levered companies are more likely to attain greater value from adopting ERM since ERM can minimize costs associated with the adverse consequences of risks [26]. [42] argued that ERM can reduce cost of capital. ERM implementation improves companies' risk profile. It is used by credit rating agency such as Standard \& Poor's to signal financial strengths of the companies. The benefit is lower cost of capital for the companies. [36] states that companies with higher leverage are more involved in ERM. In Malaysia, according to [48] ERM implementation is influenced by the company's financial leverage. Similarly, a study by [18] on 90 PLCs, finds that companies with greater financial leverage are inclined to embed ERM framework. Generally, financial leverage is likely to have positive influence on ERM adoption [26], yet the relationship between financial leverage and ERM adoption is unclear [23, 32]. According to [17], leverage has positive [36], negative [25] and no influence [9] on ERM implementation. While there is an unclear relationship between leverage and ERM implementation, studies have shown that leverage has negative relationship to firm value $[3,4,13,26,25,31]$.

\section{Matrix.}

In risk management, matrix is used to assess risks. The matrix is called risk matrix. A risk matrix is a graphical representation of risks. Risks are mapped on a graph, with the vertical axis representing likelihood or probability and the horizontal axis representing impact or magnitude [43]. The matrix is divided into four quadrants: (i) low impact, low likelihood; (ii) low impact, high likelihood; (iii) high impact, low likelihood; and (iv) high impact, high likelihood.

Apart from risk management, matrix is commonly use in other areas such as growth strategies and stakeholders management. Igor Ansoff develops Ansoff Matrix [1,2]. Ansoff Matrix is a tool uses by companies to observe opportunities from both market, and product or service perspective. The matrix assists companies to develop growth strategies. The vertical axis is market perspectives, and the horizontal axis is the service or product perspective. Ansoff Matrix is also divided into four quadrants (i) existing product, existing market (market penetration); (ii) existing product, new market (market development); (iii) new product, existing market (product development) and (iv) new product, new market (diversification).

In 1970, Bruce Henderson creates the Boston Matrix or Growth-Share Matrix for the Boston Consulting Group [22]. The matrix assesses a product against its market share and market growth rate. Similar to Ansoff Matrix, the purpose of Boston Matrix is for companies to plan strategic growth. The vertical axis is the market growth rate and the horizontal axis is the market share. The matrix is also divided into four quadrants: (i) low market share, low market growth (dogs); (ii) low market share, high market growth (question marks); (iii) high market share, low market growth (cash cows) and (iv) high market share, high market growth (stars).

In 1991, [28] developed a power-interest matrix to group stakeholders based on power and interest. Power is stakeholders' ability to influence an organisation strategy or project resources, and interest is how interested are the stakeholders in the organisation or project succeeding. The vertical axis is the power, and the horizontal axis is the interest. The purpose of the matrix is to assist an 
organisation or project leader to manage their stakeholders strategically. The matrix is also divided into four quadrants (i) low power, low interest (monitor); (ii) low power, high interest (keep informed); (iii) high power, less interest (keep satisfied and (iv) high power, high interest (manage closely).

\section{Methodology}

\subsection{Companies Selected for the Study}

This study focuses on the industry with the highest risk namely energy (oil and gas), utilities, telecommunications, and media. As stated by [15], utilities, telecommunications, and oil \& gas are the industries with the highest risk. The PLCs are selected using purposive sampling. The selection criteria are (i) the companies issue annual reports and audited financial statements as at 31st December 2016 and 31st December 2017, and (ii) the annual reports are available on the company's or Bursa Malaysia website. The annual reports are a form of corporate information verified by an independent auditing process and officially published for stakeholders. Annual reports published on a company's website reflect the official disclosure of corporate information to stakeholders. Initially, 64 PLCs are selected for data collection (32 from Energy, 13 from Utilities, and 19 from Telecommunications and Media sectors). However, 20 companies do not meet the selection criteria and removes from the sample. The final sample consists of 44 companies. Table 1 provides the name of the PLCs. Table 2 presents the numbers of sample companies against total number of companies listed in Bursa Malaysia.

\section{Table 1}

List of PLCs

\begin{tabular}{|c|c|}
\hline Energy (22 companies) & Telecommunications \& Media (12 companies) \\
\hline Alam Maritim Resources Berhad & Asia Media Group Berhad \\
\hline Bumi Armada Berhad & Axiata Group Berhad \\
\hline Barakah Offshore Petroleum Berhad & DIGI.COM Berhad \\
\hline Daya Materials Berhad & Green Packet Berhad \\
\hline Dayang Enterprise Holdings Berhad & Maxis Berhad \\
\hline Deleum Berhad & Media Prima Berhad \\
\hline Handal Resources Berhad & OCK Group Berhad \\
\hline Hengyuan Refining Company Berhad & Seni Jaya Corporation Berhad \\
\hline Sino Hua-An International Berhad & Star Media Group Berhad \\
\hline Icon Offshore Berhad & TIME DOTCOM Berhad \\
\hline KNM Group Berhad & Telekom Malaysia Berhad \\
\hline Malaysia Marine and Heavy Engineering Holdings Berhad & Utusan Melayu (Malaysia) Berhad \\
\hline Petra Energy Berhad & Utilities (10 companies) \\
\hline Perdana Petroleum Berhad & Eden Inc. Berhad \\
\hline PETRON Malaysia Refining \& Marketing Berhad & Gas Malaysia Berhad \\
\hline Reach Energy Berhad & Kumpulan Perangsang Selangor Berhad \\
\hline Serba Dinamik Holdings Berhad & Malakoff Corporation Berhad \\
\hline Sumatec Resources Berhad & Mega First Corporation Berhad \\
\hline T7 Global Berhad & PBA Holdings Berhad \\
\hline TH Heavy Engineering Berhad & PETRONAS Gas Berhad \\
\hline Velesto Energy Berhad (UMW) & Ranhill Holdings Berhad \\
\hline Wah Seong Corporation Berhad & Salcon Berhad \\
\hline & Taliworks Corporation Berhad \\
\hline
\end{tabular}




\section{Table 2}

Sample versus Total Companies

\begin{tabular}{lccc}
\hline Sector & $\begin{array}{c}\text { Total number of } \\
\text { companies listed in } \\
\text { Bursa Malaysia }\end{array}$ & $\begin{array}{c}\text { Number of companies } \\
\text { included in the study } \\
\text { (sample) }\end{array}$ & $\begin{array}{c}\text { Percentage of sample } \\
\text { vs. total companies } \\
\text { (by sector) }\end{array}$ \\
\hline Energy & 32 & 22 & $68 \%$ \\
\hline Utilities & 13 & 10 & $77 \%$ \\
\hline $\begin{array}{l}\text { Telecommunications and } \\
\text { Media }\end{array}$ & 19 & 12 & $63 \%$ \\
\hline Total & 64 & 44 & - \\
\hline
\end{tabular}

\subsection{Data Collection and Duration of Study}

Data are collected from published annual reports for the financial years end 31st December 2016 and 31st December 2017.

\subsection{Variables}

This study adopts the ERM Score develops by [9] to measure ERM implementation. Company size (FSIZE) is proxy by log of total revenue. Company leverage (FLEV) is proxy by ratio of total liabilities to equities.

\subsection{Data Analysis}

\subsubsection{Descriptive Statistics.}

Descriptive statistics are calculated for all variables. The statistics include arithmetic mean, standard deviation (SD), maximum (Max) and minimum (Min).

\subsubsection{ERM Score.}

The ERM score is obtained using a questionnaire consists of 70 items. The questions are based on eight dimensions of COSO ERM components. The assessment results are either " 0 " for absence or " 1 " for the presence of an item in the company's annual report. The range of score is between 0 and 70. The average aggregated scores of items are then calculated into a total ERM Score for a company. ERM Score of $0 \%$ represents no ERM implementation and a score of $100 \%$ represents full ERM implementation. Table 3 presented an example of ERM score questionnaire and calculation. The ERM scores are plotted in bar charts to observe the companies' ERM implementation levels based on sectors, and company size and leverage.

\subsubsection{ERM Behaviour Matrix.}

Motivated by Ansoff Matrix, Boston Matrix and Mendelow Matrix, this study develops a 3 by 3 matrix named ERM Behaviour Matrix. The purpose is to understand changes in ERM implementation as company sizes and leverage changes. The Cambridge Dictionary defines behaviour as the way that a person, an animal, or a substance behaves in a particular situation or under particular conditions. For example, changes in consumers purchasing behaviours towards organic foods are driven by consumers' health consciousness and knowledge [41]. The ERM Matrix Behaviour provides insights to changes in ERM implementation against companies' size and leverage. The matrix map ERM 
implementation based on three variables: ERM Score, Company Size and Company Leverage. The ERM Behaviour Matrix is two-dimensional. The vertical axis, the $y$-axis represents the ERM implementation proxy by ERM Score. The horizontal axis, the $x$-axis represents the ERM implementation factors, the company size and leverage. The ERM behaviour is grouped into 3 types: increase, decrease and status quo. The matrix is divided into nine quadrants, representing nine types of ERM behaviour. Table 4 presents the matrix and the ERM behaviours of each quadrant. Number of companies mapped into each quadrants in the matrix represents number of observations

Table 4

Guide to ERM Behaviour Matrix

$y$ (ERMS)

\begin{tabular}{c|ccc} 
Increase & $\begin{array}{c}\text { Negative } \\
\text { Behaviour }\end{array}$ & $\begin{array}{c}\text { Status quo } \\
\text { Behaviour }\end{array}$ & $\begin{array}{c}\text { Positive } \\
\text { Behaviour }\end{array}$ \\
Status quo & $\begin{array}{c}\text { Status quo } \\
\text { Behaviour }\end{array}$ & $\begin{array}{c}\text { Status quo } \\
\text { Behaviour }\end{array}$ & $\begin{array}{c}\text { Status quo } \\
\text { Behaviour }\end{array}$ \\
Decrease & $\begin{array}{c}\text { Positive } \\
\text { Behaviour }\end{array}$ & $\begin{array}{c}\text { Status quo } \\
\text { Behaviour }\end{array}$ & $\begin{array}{c}\text { Negative } \\
\text { Behaviour }\end{array}$ \\
\cline { 2 - 4 } & Decrease & Status quo & Increase \\
(FSIZE/FLEV)
\end{tabular}

Table 3

Questionnaire and Calculation of ERM Score (Alam Maritim Resources Berhad)

\begin{tabular}{|c|c|c|}
\hline NO & ERM COMPONENTS & YES (1) NO (0) \\
\hline & INTERNAL ENVIRONMENT & \\
\hline 1 & Is there a charter of the board? & 1 \\
\hline 2 & Information on the code of conduct/ethics? & 1 \\
\hline 3 & Information on how compensation policies align interest of managers with shareholders? & 1 \\
\hline 4 & Information on individual performance targets? & 1 \\
\hline 5 & Information on procedures for hiring and firing of board member and management? & 1 \\
\hline 6 & Information on remuneration policy of board members and management? & 1 \\
\hline 7 & Information on training, coaching and educational programs? & 1 \\
\hline 8 & Information on training in ethical values? & 1 \\
\hline 9 & Information on board responsibility? & 1 \\
\hline 10 & Information on audit committee responsibility? & 1 \\
\hline \multirow[t]{2}{*}{11} & Information on CEO responsibilities? & 1 \\
\hline & OBJECTIVE SETTING & \\
\hline 12 & Information on company's mission? & 1 \\
\hline 13 & Information on company's strategy? & 1 \\
\hline 14 & Information on company's business objectives? & 1 \\
\hline 15 & Information on adopted benchmarks to evaluate results? & 0 \\
\hline \multirow[t]{3}{*}{16} & Information on approval of the strategy by the board? & 1 \\
\hline & RISK IDENTIFICATION AND ASSESSMENT & \\
\hline & Financial risk & \\
\hline 17 & Information on extent of liquidity? & 1 \\
\hline 18 & Information on interest rate? & 1 \\
\hline 19 & Information on the foreign exchange rate? & 1 \\
\hline
\end{tabular}




\begin{tabular}{|c|c|c|}
\hline NO & ERM COMPONENTS & YES (1) NO (0) \\
\hline 20 & Information on the cost of capital? & 1 \\
\hline 21 & Information on the access to the capital market? & 1 \\
\hline \multirow[t]{2}{*}{22} & Information of long-term debt instruments? & 1 \\
\hline & Compliance risk & \\
\hline 23 & Information on litigation issues? & 1 \\
\hline 24 & Information on compliance with regulation? & 1 \\
\hline 25 & Information on compliance with industry codes? & 0 \\
\hline 26 & Information on compliance with voluntary codes? & 0 \\
\hline \multirow[t]{2}{*}{27} & Information on compliance with recommendation of Corporate Governance? & 1 \\
\hline & Technology risk & \\
\hline 28 & Information on data management? & 1 \\
\hline 29 & Information on computer systems? & 1 \\
\hline \multirow[t]{2}{*}{30} & Information on the privacy of the information held on customers? & 1 \\
\hline & Economical risk & \\
\hline \multirow[t]{2}{*}{31} & Information on the nature of competition? & 1 \\
\hline & Reputational risk & \\
\hline 32 & Information on environmental issues? & 1 \\
\hline 33 & Information on ethical issues? & 1 \\
\hline \multirow[t]{3}{*}{34} & Information on health and safety issues? & 1 \\
\hline & RISK RESPONSE & \\
\hline & Financial risk & \\
\hline 35 & General description of risk processes for determining how risk should be managed? & 1 \\
\hline 36 & Information on written risk guidelines about how risk should be managed? & 1 \\
\hline 37 & Response to the liquidity risk? Liquidity risk response & 1 \\
\hline 38 & Response to the interest rate risk? & 1 \\
\hline 39 & Response to the foreign exchange rate risk? & 1 \\
\hline 40 & Response to the risk related to cost of capital risk. & 1 \\
\hline 41 & Response to the access to the capital market? & 1 \\
\hline \multirow[t]{2}{*}{42} & Response to long-term debt instruments? & 1 \\
\hline & Compliance risk & \\
\hline 43 & Response to litigation risk? & 0 \\
\hline 44 & Response to compliance with regulation risk? & 1 \\
\hline 45 & Response to compliance with industry codes? & 0 \\
\hline 46 & Response to compliance with voluntary codes? & 0 \\
\hline \multirow[t]{2}{*}{47} & Response to compliance with recommendation of Corporate Governance? & 1 \\
\hline & Technology risk & \\
\hline 48 & Response to data risk? & 1 \\
\hline 49 & Response to computer system risk? & 1 \\
\hline \multirow[t]{2}{*}{50} & Response to the privacy of information held on customers. & 1 \\
\hline & Economical risk & \\
\hline \multirow[t]{2}{*}{52} & Response to the competition risk? & 0 \\
\hline & Reputational risk & \\
\hline 53 & Response to environmental risk? & 1 \\
\hline 54 & Response to ethical risk? & 1 \\
\hline \multirow[t]{2}{*}{55} & Response to health and safety risk? & 1 \\
\hline & CONTROL ACTIVITIES & \\
\hline
\end{tabular}




\begin{tabular}{|c|c|c|}
\hline NO & ERM COMPONENTS & YES (1) NO (0) \\
\hline 56 & Information on sales control? & 0 \\
\hline 57 & Information on contingency plans or DRP (Disaster recovery plans)? & 0 \\
\hline 58 & Information on review of the functioning and effectiveness of controls? & 0 \\
\hline 59 & Information on segregation of duties? & 1 \\
\hline 60 & Information on authorisation issues? & 1 \\
\hline 61 & Information on documents and record as control? & 1 \\
\hline 62 & Information on independent verification procedures? & 0 \\
\hline 63 & Information on physical controls? & 1 \\
\hline \multirow[t]{2}{*}{64} & Information on process control? & 1 \\
\hline & INFORMATION AND COMMUNICATIONS & \\
\hline 65 & Information on verification of completeness, accuracy and validity of information? & 1 \\
\hline 66 & $\begin{array}{l}\text { Information on channels of communication to report suspected breaches of laws, regulations } \\
\text { or other improper. }\end{array}$ & 1 \\
\hline \multirow[t]{2}{*}{67} & $\begin{array}{l}\text { Information on channels of communication with customers, vendors and other external } \\
\text { parties? }\end{array}$ & 1 \\
\hline & MONITORING & \\
\hline 68 & Information on how processes are monitored? & 1 \\
\hline 69 & Information about Internal Audit? & 1 \\
\hline \multirow[t]{3}{*}{70} & Information about the budget of the Internal Audit? & 0 \\
\hline & Total & 58 \\
\hline & Total Weighted Average ERM Score (in percentage) & 0.8285 \\
\hline
\end{tabular}

ERM Behaviour is a function of ERM Score, Company Size and Company Leverage. Based on Table 4, the equations for the ERM Behaviour Matrix are as follows.

Positive Behaviour $=\sum_{i=1}^{n} n_{y_{\uparrow}, x_{\uparrow}}+\sum_{i=1}^{n} n_{y_{\downarrow}, x_{\downarrow}}$

Negative Behaviour $=\sum_{i=1}^{n} n_{y_{\uparrow}, x_{\downarrow}}+\sum_{i=1}^{n} n_{y_{\downarrow}, x_{\uparrow}}$

Status Quo Behaviour $=\sum_{i=1}^{n} n_{y_{\equiv}, x_{\equiv}}+\sum_{i=1}^{n} n_{y_{\equiv}, x_{\uparrow}}+\sum_{i=1}^{n} n_{y_{\equiv}, x_{\downarrow}}+\sum_{i=1}^{n} n y_{\uparrow}, x_{\equiv}+\sum_{i=1}^{n} n_{y_{\downarrow}, x_{\equiv}}$

$n$ is number of companies

$y$ is $y$-axis representing ERM Score

$x$ is $x$-axis representing Company Size and Company Leverage

$\mathrm{Y} \uparrow$ is increase ERM Score from 2016 to 2017

$y_{\downarrow}$ is decrease ERM Score from 2016 to 2017

$y_{\equiv}$ is status quo or no changes in ERM score from 2016 to 2017

$X \uparrow$ is increase in company size or company leverage from 2016 to 2017

$x_{\downarrow}$ is decrease in company size or company leverage from 2016 to 2017

$x \equiv$ is status quo or no changes in company size or company leverage from 2016 to 2017 


\section{Results}

\subsection{Descriptive Statistics}

Table 5 presents descriptive results of the mean, standard deviation, minimum and maximum values of the dependent, independent, dummy and control variables. The ERMS has a mean score of $79 \%$ with a minimum score of $43 \%$ and a maximum score of $97 \%$. The result shows all companies implement ERM. However, the level of implementation varies. Company size shows a mean of RM 8.70 billion, ranging from a minimum of RM 6.57 billion to a maximum of RM 10.39 billion. The mean of company leverage is 1.66. Minimum company leverage is 0.03 to a maximum of 14.54 .

Table 5
Descriptive Results

\subsection{ERM Score by Sectors}

\subsubsection{Energy Sector}

Figure 1 presents ERM Score for the Energy sector. An average 2-year ERM Score for the Energy sector was 79.5\%. In 2016, the maximum score is $96 \%$ by Dayang Enterprise Holdings Berhad and the minimum score is $60 \%$ by Perdana Petroleum Berhad. The average ERM Score in 2016 is 79\%. In 2017, the maximum score is $94 \%$ by Wah Seong Corporation Berhad and the minimum score is $61 \%$ by T7 Global Berhad. The average ERM Score in 2017 is $80 \%$. Looking at the differences between the 2-year ERM Score, 12 out of 22 companies (55\%) improve their ERM implementation. The companies are Alam Maritim, Daya Materials, Deleum Berhad, Henngyuan, Sino Hua-An, Icon Offshore, MMHE, Petra Energy, Perdana, TH Heavy, Velesto Ebergy and Wah Seoing. Perdana Petroleum Berhad, has the lowest ERM Score in 2016. However, the company records the highest increment of $20 \%$ in their ERM Score in 2017. Seven out of 22 companies (32\%) show decline in their ERM implementation in 2017. The companies are Bumi Armada, Barakah Offshore, Dayang Enterprise, Handal Resources, Reach Energy, Serba Dinamik and T7 Global Berhad. T7 Global Berhad recorded the lowest declined in ERM Score of $17 \%$ in 2017 compared to 2016. The remaining 3 companies, PETRON Malaysia Refining \& Marketing Berhad, Serba Dinamik Holdings Berhad and Sumatec Resources Berhad show status quo in their ERM Score from 2016 and 2017.

\subsubsection{Utilities Sector}

Figure 2 presents ERM Score for the Utilities sector. The average 2-year ERM Score for the utilities sector is 84\%. PETRONAS Gas Berhad records the highest ERM Score of 94\% and 97\% for 2016 and 2017, respectively. On the contrary, Eden Inc. Berhad records the lowest ERM Score of 70\% and 69\% for 2016 and 2017, respectively. The average ERM Score in 2016 was $82 \%$ and $86 \%$ in 2017. Looking at the differences of ERM Score between the 2-year shows, 8 out of 10 companies improved their ERM implementation. The companies are Gas Malaysia Berhad, Kumpulan Perangsang, Malakoff Corporation Berhad, Mega First Corporation Berhad, PBA Holdings Berhad, Petronas Gas Berhad, Ranhill Holdings Berhad and Taliworks Corporation Berhad. PBA Holding Berhad records the highest 
increment of 11\% in their ERM Score in 2017 from 2016. Salcon Berhad records the lowest ERM Score decrement of 4\% in 2017 from 2016. Two out of 10 companies, Eden Inc. Berhad and Salcon Berhad experience reduction in ERM Score in 2017 from 2016. There was no status quo ERM Score by companies in the utilities sector.

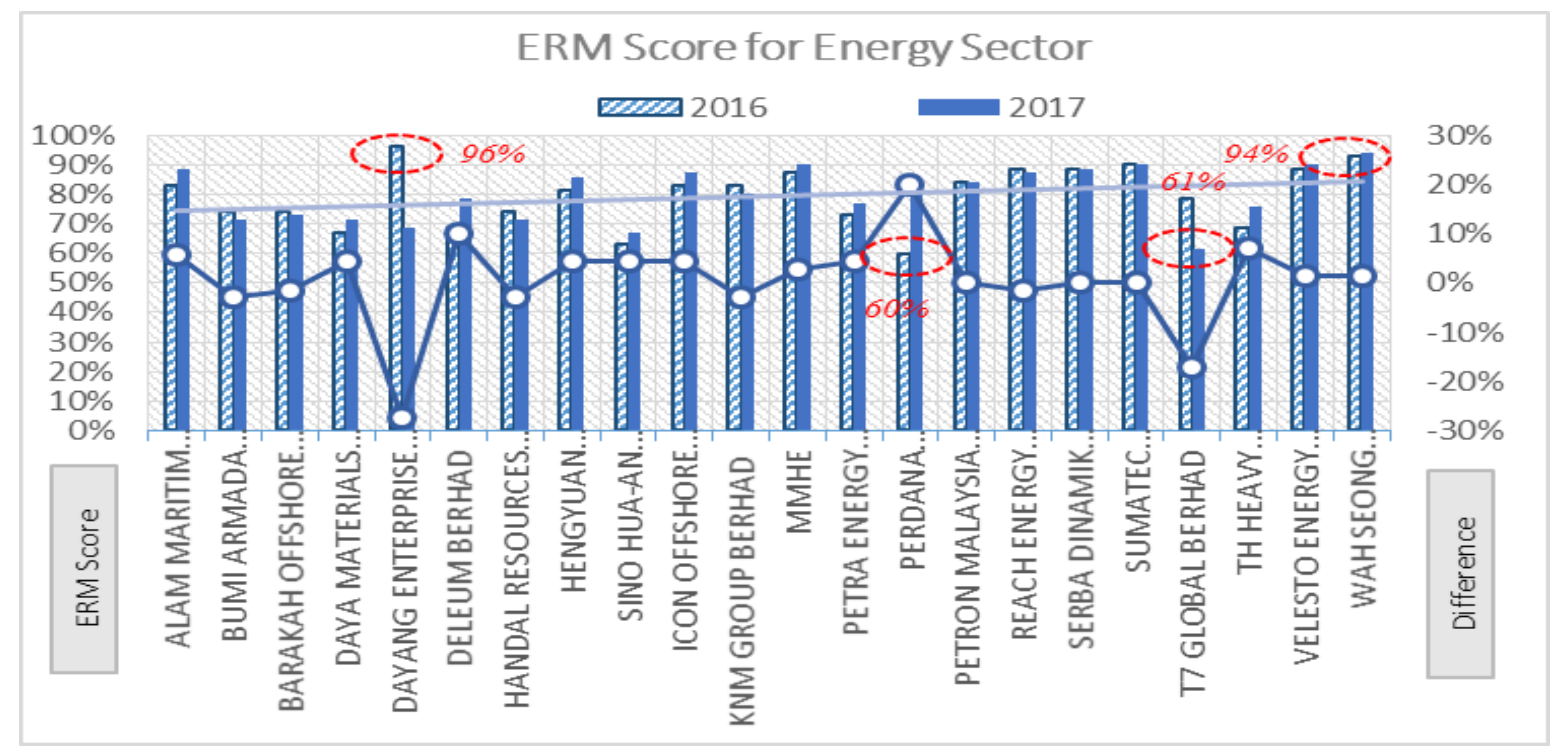

Fig. 1. ERM Score for Energy Sector

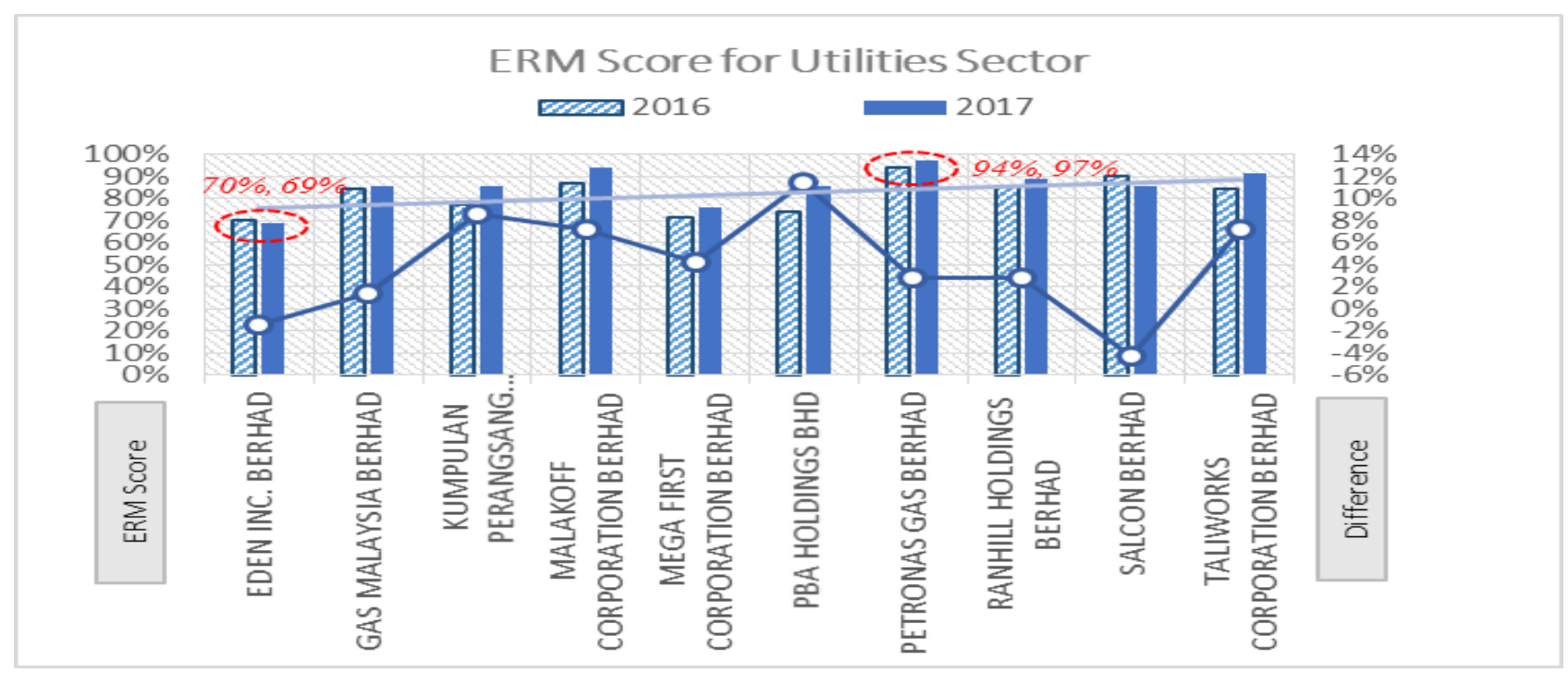

Fig. 2. ERM Score for Utilities Sector

\subsubsection{Telecommunication and Media Sector}

Figure 3 presents ERM Score for the Telecommunications and Media sector. The average 2-year ERM Score for the Telecommunications and Media sector is $74 \%$. In 2016, the maximum score is $93 \%$ by Axiata Group Berhad and the minimum score is $43 \%$ by Green Packet Berhad. The average ERM Score in 2016 is 73\%. In 2017, the maximum score is $90 \%$ by Star Media Group Berhad and the minimum score is $60 \%$ by Asia Media Group Berhad. The average ERM Score in 2017 is 76\%. Looking at the differences between the 2-year ERM Score, 7 out of 12 companies improve their ERM score. 
The companies are Asia Media Group, Green Packet Berhad, Maxis Berhad, Star Media Berhad, Time Dot Com, Telekom Malaysia and Utusan Melayu. Green Packet Berhad, the company with the lowest ERM Score in 2016 records the highest increment of 20\% in 2017 from 2016. Four out of 12 companies experience reduction in their ERM Score in 2017. The companies are Axiata Group Berhad, Digi.Com Berhad, Media Prima Berhad and Seni Jaya Berhad. Axiata Group Berhad has the highest ERM Score in 2016. However, the company records reduce ERM Score of 14\% in 2017 from 2016. OCK Group Berhad ERM Score remain unchanged in 2016 and 2017.

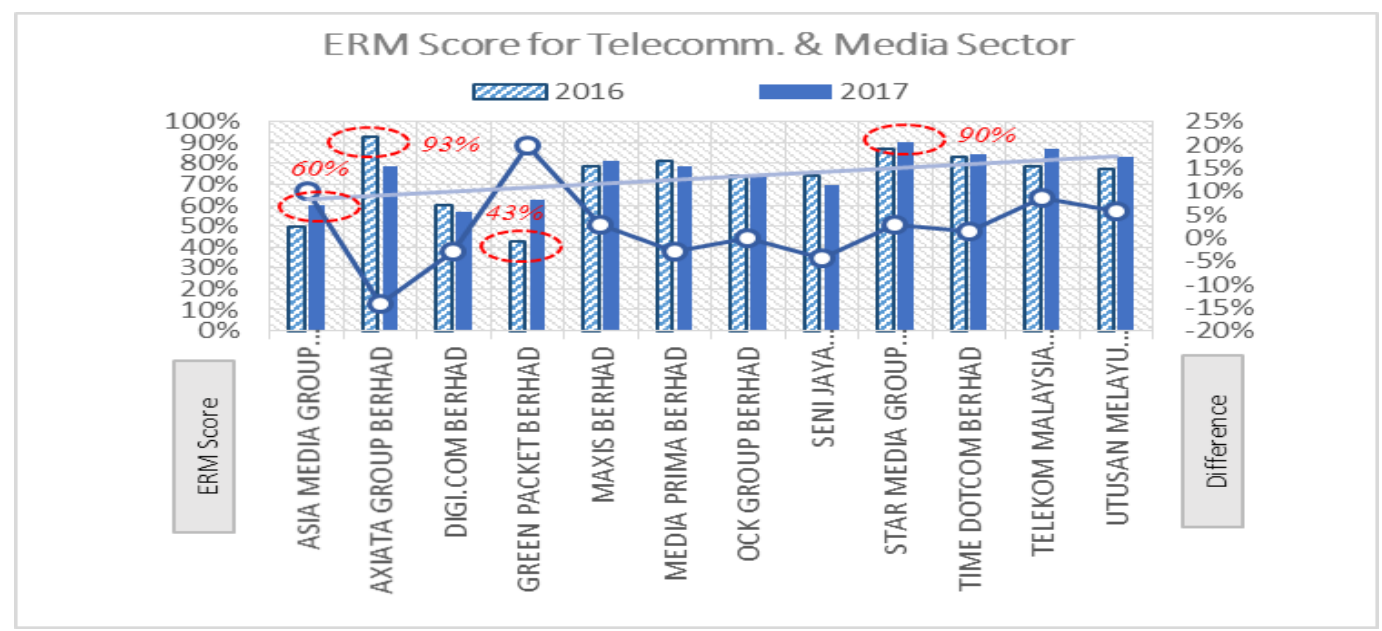

Fig. 3. ERM Score for Telecommunications and Media Sector

\subsection{ERM Score by Company Size and Leverage}

Figure 4 presents ERM Score by company size. The results show company size drives ERM implementation. Companies with high total revenues have high ERM Score. Figure 5 presents ERM Score by company leverage. Leverage is proxy by total liabilities divided by total equities. Similarly, the results show leverage drives ERM implementations. Companies with high leverages have high ERM Score.

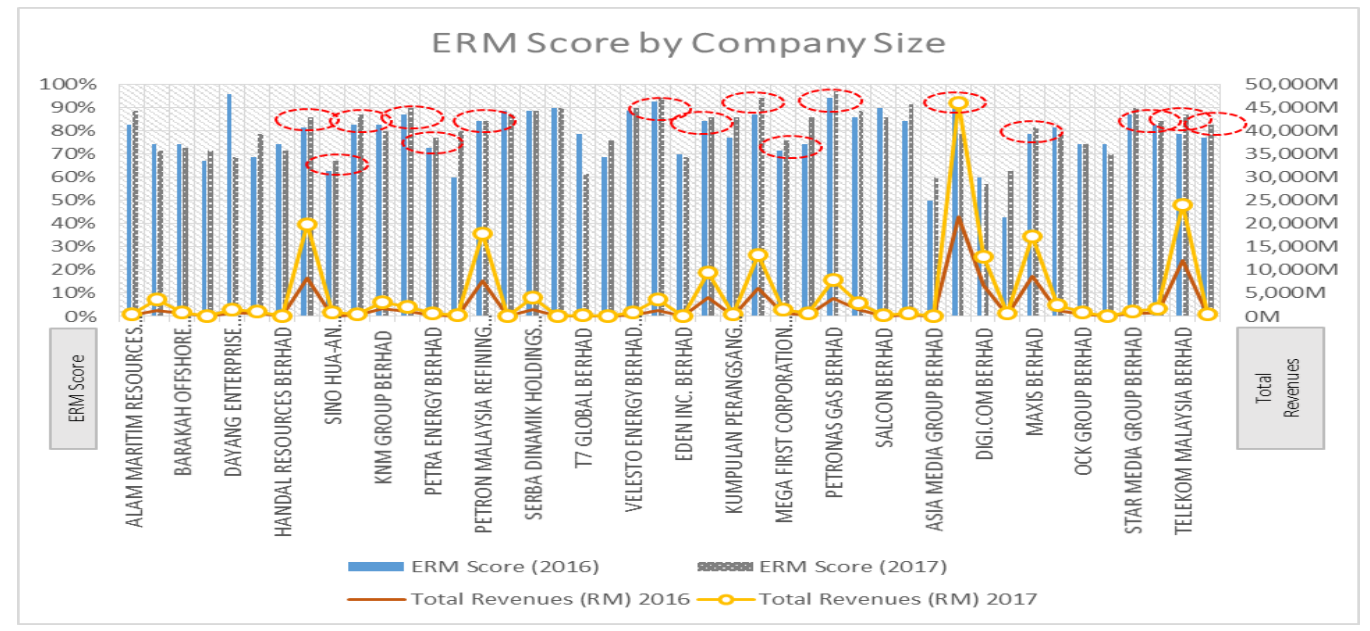

Fig. 4. ERM Score by Company Size 


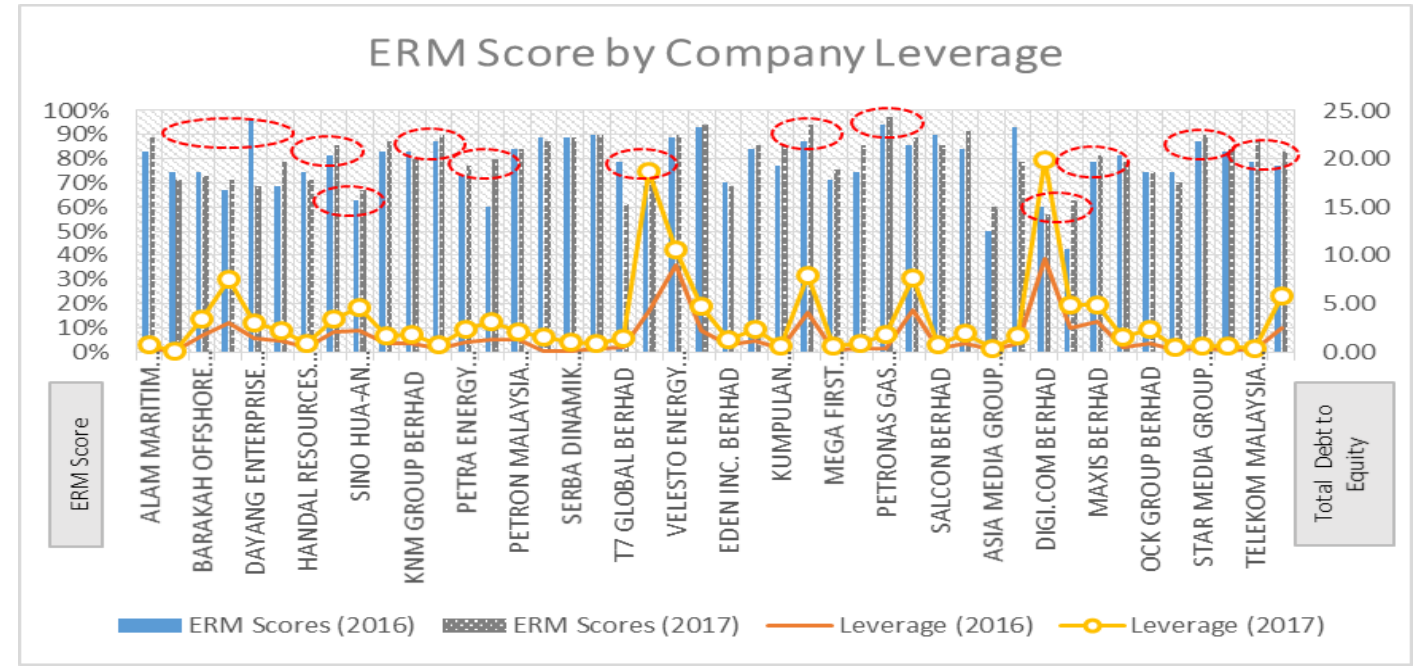

Fig. 5. ERM Score by Company Leverage

\subsection{ERM Behaviour Matrix}

Figure 6 presents the ERM Behaviour Matrix of ERM implementation and company size. Table 6 presents the number of companies in each quadrant. Based on the results, $52 \%$ of the companies shows positive behaviour, $32 \%$ negative behaviour, and $18 \%$ status-quo behaviour. Figure 7 presents the ERM Behaviour Matrix for company leverage and Table 7 presents the numbers of observations. Based on the results, $43 \%$ of the companies shows positive behaviour, $39 \%$ negative behaviour, and $18 \%$ shows status-quo behaviour.

\section{Discussion}

The average level of ERM implementation by non-financial PLCs is 79\%. The result contradicts the finding by [34]. [34] argued that ERM implementation is still low and only $30 \%$ of the PLCs in Malaysia implement ERM. This study concludes that non-financial PLCs of high-risk sectors, energy, utilities, and telecommunications and media, implements ERM. However, the level of implementation varies between sectors and within the same sectors. This study develops the ERM Behaviour Matrix. The purpose of the matrix is to observe the behaviour of ERM implementation against company size and leverage. For ERM implementation and company size, the ERM behaviour is positive i.e. company size is a driver to ERM implementation. As company size increases, so does ERM implementation. Likewise, as company size decreases, ERM implementation decreases as well. These observations are parallel with previous studies $[5,11,17,23,25,36,18,46]$. These studies find large companies implement ERM. For ERM implementation and leverage, the behaviour matrix also shows positive behaviours, i.e. leverage is a driver to ERM implementation. As leverage increases, so does ERM implementation. Likewise, as leverage decreases, ERM implementation decreases as well. Using a simple behaviour matrix this study agrees with the positive findings of leverage and ERM implementation by [18, 36, 48]. Results of this study disagrees with [23] and [32]. Both studies find the relationship between financial leverage and ERM adoption is unclear. In terms of behaviour, company size and leverage are the drivers or stimulus for ERM implementation. 


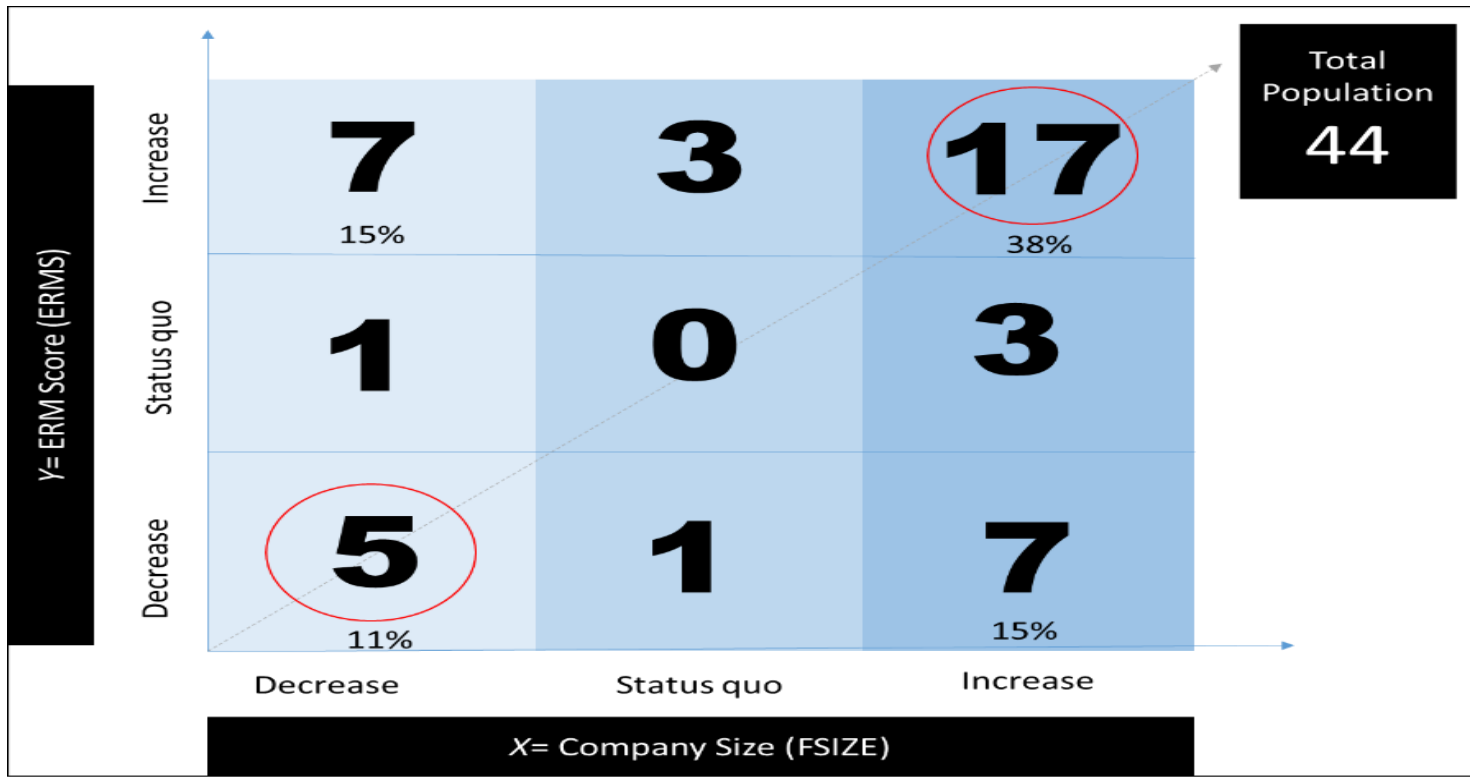

Fig. 6. ERM Behaviour Matrix: ERM Score and Company Sizes

Table 6

ERM Behaviour Matrix: ERM Score (ERMS) and Company Sizes (FSIZE)

\begin{tabular}{cccccc}
\hline $\begin{array}{c}\text { ERM } \\
\text { Behaviour }\end{array}$ & Changes & $\begin{array}{c}\text { No of } \\
\text { Company }\end{array}$ & Changes & No of Company & $\begin{array}{c}\text { Total No. of } \\
\text { Company }\end{array}$ \\
\hline $\begin{array}{c}\text { Positive } \\
\text { behaviour }\end{array}$ & $\begin{array}{c}\text { ERMS increase, } \\
\text { FSIZE increase }\end{array}$ & 17 & $\begin{array}{c}\text { ERMS decrease, } \\
\text { FSIZE decrease }\end{array}$ & 5 & 22 \\
\hline $\begin{array}{c}\text { Negative } \\
\text { behaviour }\end{array}$ & $\begin{array}{c}\text { ERMS increase, } \\
\text { FSIZE decrease }\end{array}$ & 7 & $\begin{array}{c}\text { ERMS decrease, } \\
\text { FSIZE increase }\end{array}$ & 7 & 14 \\
\hline $\begin{array}{c}\text { ERMS status quo, } \\
\text { FSIZtus quatus quo } \\
\text { behaviour }\end{array}$ & $\begin{array}{c}\text { ERMS status quo, } \\
\text { FSIZE increase } \\
\text { ERMS status quo, } \\
\text { FSIZE decrease }\end{array}$ & 3 & $\begin{array}{c}\text { ERMS increase, } \\
\text { FSIZE status quo } \\
\text { ERMS decrease, } \\
\text { FSIZE status quo }\end{array}$ & 3 & 3 \\
\hline
\end{tabular}

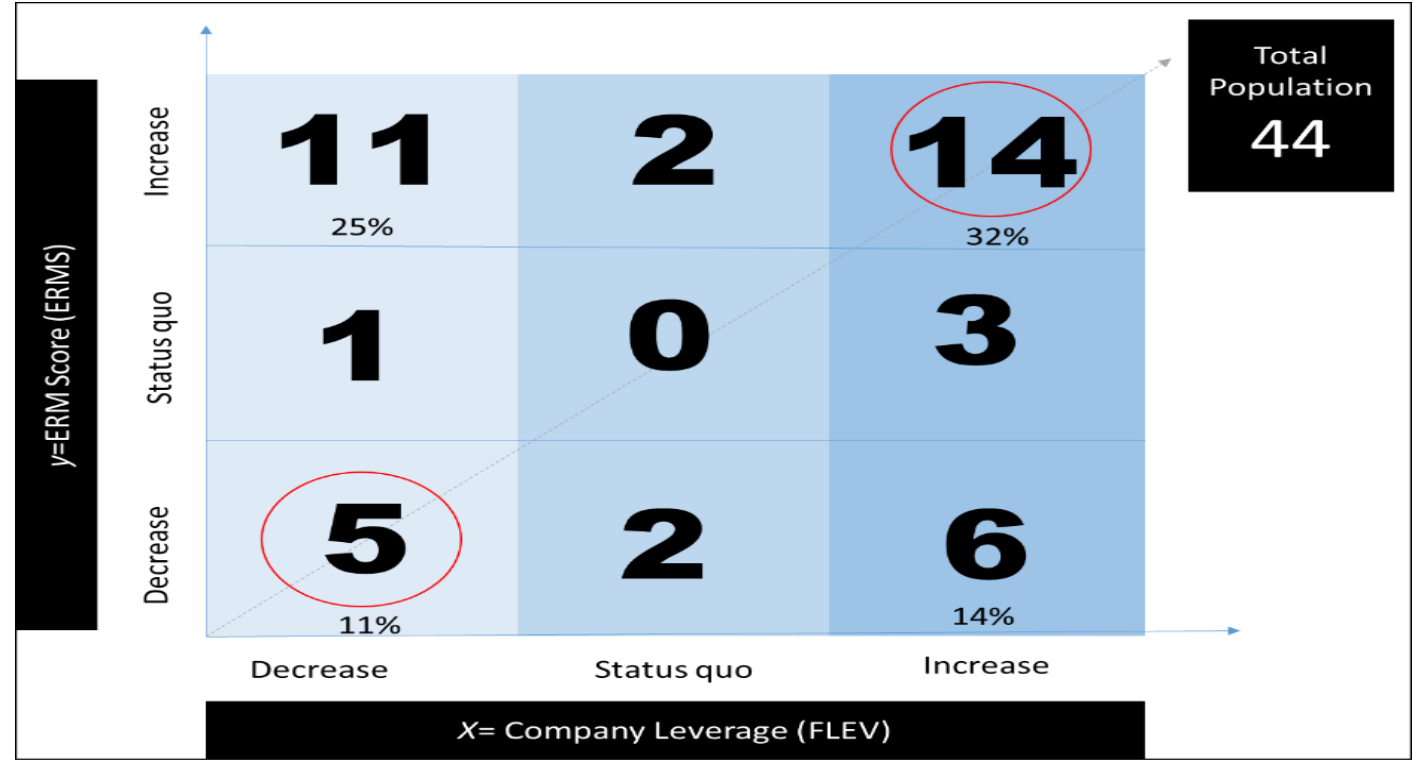

Fig. 7. ERM Behaviour Matrix: Company Leverage 
Table 7

ERM Behaviour Matrix: ERM Score (ERMS) and Company Leverage (FLEV)

\begin{tabular}{|c|c|c|c|c|c|}
\hline $\begin{array}{c}\text { ERM } \\
\text { Behaviour }\end{array}$ & Changes & $\begin{array}{c}\text { No of } \\
\text { Company }\end{array}$ & Changes & $\begin{array}{c}\text { No of } \\
\text { Company }\end{array}$ & $\begin{array}{l}\text { Total No } \\
\text { Company }\end{array}$ \\
\hline $\begin{array}{l}\text { Positive } \\
\text { behaviour }\end{array}$ & $\begin{array}{l}\text { ERMS increase, } \\
\text { FLEV increase }\end{array}$ & 14 & $\begin{array}{l}\text { ERMS decrease } \\
\text { FLEV decrease }\end{array}$ & 5 & 19 \\
\hline $\begin{array}{l}\text { Negative } \\
\text { behaviour }\end{array}$ & $\begin{array}{l}\text { ERMS increase, } \\
\text { FLEV decrease }\end{array}$ & 11 & $\begin{array}{l}\text { ERMS decrease } \\
\text { FLEV increase }\end{array}$ & 6 & 17 \\
\hline \multirow{3}{*}{$\begin{array}{l}\text { Status quo } \\
\text { behaviour }\end{array}$} & $\begin{array}{l}\text { ERMS status quo, } \\
\text { FLEV status quo }\end{array}$ & 0 & $\begin{array}{l}\text { ERMS increase. } \\
\text { FLEV status quo }\end{array}$ & 2 & 2 \\
\hline & $\begin{array}{l}\text { ERMS Status quo, } \\
\text { FLEV increase }\end{array}$ & 3 & $\begin{array}{l}\text { ERMS decrease, } \\
\text { FLEV status quo }\end{array}$ & 2 & 5 \\
\hline & $\begin{array}{l}\text { ERMS status quo, } \\
\text { FLEV decrease }\end{array}$ & 1 & & & 1 \\
\hline
\end{tabular}

\section{Limitations and Future Study}

The context of the study is limited to high-risk sectors of energy, utilities, telecommunications and media sectors, leading to a small sample size that limited the generalizability of findings to all non-financial sectors and companies in Malaysia. This study only covered data of 2-year period from 2016 to 2017. Collecting 2 years of data from annual reports of 44 companies are practical and doable. However, the 2-year data may not be sufficient to get comprehensive views of ERM implementation in relation to company size and leverage. This study uses the ERM Score develops by [9], to measure ERM implementation. The ERM Score is easy to use. However, the score is not developed for Malaysian PLCs environment and it is based on the COSO ERM Framework. It is a challenge to pin down a good representative measure of ERM implementation level for the Malaysian setting. Future studies may consider looking at a larger sample, including other sectors such as Consumer Products \& Services, Industrial Products \& Services, Technology, Construction, and Property, representing the entire population of non-financial sectors in Malaysia. Future studies may develop an ERM score to measure level of ERM implementation in Malaysia. The ERM score may incorporate other global risk management standards and guidelines such as published by International Organization for Standardization (ISO).

\section{Conclusion}

This study contributes to enhance understanding on ERM implementation in Malaysian nonfinancial PLCs. Despite ERM considered as a new concept, PLCs in Malaysia do implement ERM in their organisation. However, the level of implementations varies according to sectors, firm size and leverage. This study develops ERM Behaviour Matrix to capture changes in ERM implementations against changes in firm size and leverage. Larger companies and companies with high leverage have higher level of ERM implementation. Smaller companies and companies with low leverage have lower level of ERM implementation. Indicating that larger companies have the resources to implement ERM. As companies become larger, the risks become more complex. Hence, the need to increase ERM implementation. As companies' rely more on liability to finance their operation, the higher is the risk of not being able to pay off the debt. Hence, increasing the needs to manage risks, through increasing level of ERM implementation. 


\section{References}

[1] Ansoff, H. Igor. "Strategies for diversification". Harvard Business Review 35, no. 5 (1957): 113-124.

[2] Ansoff, H. Igor, Daniel Kipley, A. O. Lewis, Roxanne Helm-Stevens, and Rick Ansoff. Implanting Strategic Management. Springer, 2018.

https://doi.org/10.1007/978-3-319-99599-1

[3] Baxter, Ryan, Jean C. Bedard, Rani Hoitash, and Ari Yezegel. "Enterprise risk management program quality: Determinants, value relevance, and the financial crisis." Contemporary Accounting Research 30, no. 4 (2013): 1264 1295. https://doi.org/10.1111/i.1911-3846.2012.01194.x

[4] Bertinetti, Giorgio Stefano, Elisa Cavezzali, and Gloria Gardenal. "The effect of the enterprise risk management implementation on the firm value of European companies." Department of Management, Università Ca'Foscari Venezia Working Paper 10 (2013). https://doi.org/10.2139/ssrn.2326195

[5] Beasley, Mark S., Richard Clune, and Dana R. Hermanson. "Enterprise risk management: An empirical analysis of factors associated with the extent of implementation." Journal of Accounting and Public Policy 24, no. 6 (2005): 521-531.

https://doi.org/10.1016/j.jaccpubpol.2005.10.001

[6] Beasley, Mark, Don Pagach, and Richard Warr. "Information conveyed in hiring announcements of senior executives overseeing enterprise-wide risk management processes. "Journal of Accounting, Auditing \& Finance 23, no. 3 (2008): 311-332. https://doi.org/10.1177/0148558X0802300303

[7] Colquitt, L. Lee, Robert E. Hoyt, and Ryan B. Lee. "Integrated risk management and the role of the risk manager." Risk Management and Insurance Review 2, no. 3 (1999): 43-61. https://doi.org/10.1111/j.1540-6296.1999.tb00003.x

[8] Committee of the Sponsoring Organizations of the Treadway Commission (COSO). "Enterprise Risk Management, Integrated Framework (COSO ERM Report". (2004). New York: American Institute of Certified Public Accountants (AICPA). Retrieved Nov 12, 2018, from https://www.coso.org/Documents/COSO-ERM-Executive-Summary.pdf

[9] Desender, Kurt. "On the determinants of enterprise risk management implementation." In Enterprise IT Governance, Business Value and Performance Measurement, pp. 87-100. IGI Global, 2011. Available at SSRN: https://ssrn.com/abstract=1025982 https://doi.org/10.4018/978-1-60566-346-3.ch006

[10] Desender, Kurt, and Esteban Lafuente. "The influence of board composition, audit fees and ownership concentration on enterprise risk management." Working Paper. Autonomous University of Barcelona and Centre for Entrepreneurship and Business Research (CEBR). (2009). https://doi.org/10.2139/ssrn.1495856

[11] Eckles, David L., Robert E. Hoyt, and Steve M. Miller. "Reprint of: The impact of enterprise risk management on the marginal cost of reducing risk: Evidence from the insurance industry." Journal of Banking \& Finance 49 (2014): 409423.

https://doi.org/10.1016/i.jbankfin.2014.10.006

[12] Muhammad Faisal and Nida Nadya Hasan. "Enterprise Risk Management and Firm Value: The Case in Emerging Market." International Journal of Innovation, Creativity and Change 11, no. 6 (2020), 272-286.

[13] Florio, Cristina, and Giulia Leoni. "Enterprise risk management and firm performance: The Italian case." The British Accounting Review 49, no. 1 (2017): 56-74. https://doi.org/10.1016/j.bar.2016.08.003

[14] Francis, Sebastian, and Bob Paladino. "Enterprise risk management: A best practice approach." Journal of Corporate Accounting \& Finance 19, no. 3 (2008): 19-33. https://doi.org/10.1002/icaf.20382

[15] Frantz, Maurer. "How much cash is at risk? Evidence from US non-financial firms." In International Conference of the French Finance Association (AFFI). May 2011. Available at SSRN: https://ssrn.com/abstract=1833470

[16] Fraser, John, and Betty Simkins, eds. Enterprise Risk Management: Today's Leading Research And Best Practices For Tomorrow's Executives. John Wiley \& Sons, 2010.

[17] Gatzert, Nadine, and Michael Martin. "Determinants and value of enterprise risk management: Empirical evidence from the literature." Risk Management and Insurance Review 18, no. 1 (2015): 29-53.

https://doi.org/10.1111/rmir.12028 
[18] Golshan, Nargess Mottaghi, and S. Abdul Rasid. "Determinants of enterprise risk management adoption: An empirical analysis of Malaysian public listed firms." International Journal of Social and Human Sciences 6, no. 2012 (2012): 119-126.

[19] Gordon, Lawrence A., Martin P. Loeb, and Chih-Yang Tseng. "Enterprise risk management and firm performance: A contingency perspective." Journal of Accounting And Public Policy 28, no. 4 (2009): 301-327. https://doi.org/10.1016/i.jaccpubpol.2009.06.006

[20] Grace, Martin F., J. Tyler Leverty, Richard D. Phillips, and Prakash Shimpi. "The value of investing in enterprise risk management." Journal of Risk and Insurance 82, no. 2 (2015): 289-316. https://doi.org/10.1111/jori.12022

[21] Hanssen, Joe. "Corporate culture and operational risk management." Bank Accounting \& Finance 18, no. 2 (2005): 35-39.

[22] Henderson, Bruce D. "The Product Portfolio". Available at https://www.bcg.com/publications/1970/strategy-theproduct-portfolio.aspx (1970).

[23] Hoyt, Robert E., and Andre P. Liebenberg. "The value of enterprise risk management." Journal of Risk And Insurance 78, no. 4 (2011): 795-822.

https://doi.org/10.1111/j.1539-6975.2011.01413.x

[24] Kraus, V., and O. M. Lehner. "The nexus of enterprise risk management and value creation: A systematic literature review." ACRN Journal of Finance and Risk Perspectives 1, no. 1 (2012): 91-163.

[25] Lechner, Philipp, and Nadine Gatzert. "Determinants and value of enterprise risk management: empirical evidence from Germany." The European Journal of Finance 24, no. 10 (2018): 867-887. https://doi.org/10.1080/1351847X.2017.1347100

[26] Liebenberg, Andre P., and Robert E. Hoyt. "The determinants of enterprise risk management: Evidence from the appointment of chief risk officers." Risk Management and Insurance Review 6, no. 1 (2003): 37-52. https://doi.org/10.1111/1098-1616.00019

[27] Lin, Yijia, Min-Ming Wen, and Jifeng Yu. "Enterprise risk management: Strategic antecedents, risk integration, and performance." North American Actuarial Journal 16, no. 1 (2012): 1-28. https://doi.org/10.1080/10920277.2012.10590630

[28] Mendelow, Aubrey L. "Stakeholder mapping". In Proceedings of the 2nd International Conference on Information Systems, Cambridge, MA. (1991, December).

[29] Manab, Norlida Abdul, and Isahak Kassim. "A moderating effect of leadership on a success of enterprise-wide risk management practices." In Proceedings of the 3rd International Conference on Business and Economic Research (3rd ICBER 2012) Conference, Bandung, Indonesia. 2012.

[30] Manab, Norlida Abdul, Isahak Kassim, and Mohd Rasid Hussin. "Enterprise-wide risk management (EWRM) practices: Between corporate governance compliance and value." International Review of Business Research Papers 6, no. 2 (2010): 239-252.

[31] McShane, Michael K., Anil Nair, and Elzotbek Rustambekov. "Does enterprise risk management increase firm value?." Journal of Accounting, Auditing \& Finance 26, no. 4 (2011): 641-658. https://doi.org/10.1177/0148558X11409160

[32] Kaplan, R., and A. Mikes. "Managing risks: towards a contingency theory of enterprise risk management." Harvard Business Review (2013).

[33] Moeller, Robert R. COSO enterprise risk management: understanding the new integrated ERM framework. John Wiley \& Sons, 2007.

[34] Mohd-Sanusi, Zuraidah, Shayan Motjaba-Nia, Nurul A. Roosle, Ria Nelly Sari, and Agus Harjitok. "Effects of corporate governance structures on enterprise risk management practices in Malaysia." International Journal of Economics and Financial Issues 7, no. 1 (2017).

[35] Nocco, Brian W., and René M. Stulz. "Enterprise risk management: Theory and practice." Journal of Applied Corporate Finance 18, no. 4 (2006): 8-20. https://doi.org/10.1111/i.1745-6622.2006.00106.x

[36] Pagach, Donald, and Richard Warr. "The characteristics of firms that hire chief risk officers." Journal of Risk And Insurance 78, no. 1 (2011): 185-211. https://doi.org/10.1111/j.1539-6975.2010.01378.x

[37] Pooser, David M. "An empirical examination of the interrelations of risks and the firm's relation with enterprise risk management." PhD diss., The Florida State University, 2012.

[38] Gordon, Lawrence A., Martin P. Loeb, and Chih-Yang Tseng. "Enterprise risk management and firm performance: A contingency perspective." Journal of Accounting And Public Policy 28, no. 4 (2009): 301-327. https://doi.org/10.1016/i.jaccpubpol.2009.06.006 
[39] Standard \& Poor's. Credit FAQ: Enterprise Risk Management One Year On. Available at www.standardandpoors.com/ratingsdirect. (2006).

[40] Standard \& Poor's. Expanded Definition of Adequate Classification in Enterprise Risk Management Scores. Available at www.standardandpoors.com/ratingsdirect. (2010)

[41] Singh, Anupam, and Priyanka Verma. "Factors influencing Indian consumers' actual buying behaviour towards organic food products." Journal of Cleaner Production 167 (2017): 473-483. https://doi.org/10.1016/i.jclepro.2017.08.106

[42] Shad, Muhammad Kashif, Fong-Woon Lai, Chuah Lai Fatt, Jiří Jaromír Klemeš, and Awais Bokhari. "Integrating sustainability reporting into enterprise risk management and its relationship with business performance: $A$ conceptual framework." Journal of Cleaner Production 208 (2019): 415-425. https://doi.org/10.1016/i.jclepro.2018.10.120

[43] Sum, Rabihah Md. "Using Mathematics to Quantify Subjective Decisions: Application of Analytic Hierarchy Process to Risk Assessment." Journal of Advanced Research Design 44, no. 1 (2018).

[44] Tahir, Izah Mohd, and Ahmad Rizal Razali. "The Relationship between enterprise risk management (ERM) and firm value: Evidence from Malaysian public listed companies." International Journal of Economics And Management Sciences 1, no. 2 (2011): 32-41.

[45] Daud, Wan Norhayate Wan., Ahmad Shukri Yazid and Mohd Rasid Hussin. "Determinants of Enterprise Risk Management (ERM) Adoption among Malaysian Companies." Universiti Teknologi MARA, Shah Alam Selangor, MALAYSIA (2009).

[46] Daud, Wan Norhayate Wan, Ahmad Shukri Yazid, and Hj Mohd Rasid Hussin. "The effect of chief risk officer (CRO) on enterprise risk management (ERM) practices: Evidence from Malaysia." International Business \& Economics Research Journal (IBER) 9, no. 11 (2010).

https://doi.org/10.19030/iber.v9i11.30

[47] Wu, Yue, Alasdair Marshall, Maxwell Chipulu, Qiuying Li, and Udechukwu Ojiako. "Enterprise risk management and firm value within China's insurance industry." Professional Accountant 14, no. 1 (2014): 1-10. https://doi.org/10.4102/ac.v14i1.198

[48] Yazid, Ahmad Shukri, Ahmad Rizal Razali, and Mohd Rasid Hussin. "Determinants of enterprise risk management (ERM): A proposed framework for Malaysian public listed companies." International Business Research 5, no. 1 (2012): 80.

https://doi.org/10.5539/ibr.v5n1p80 